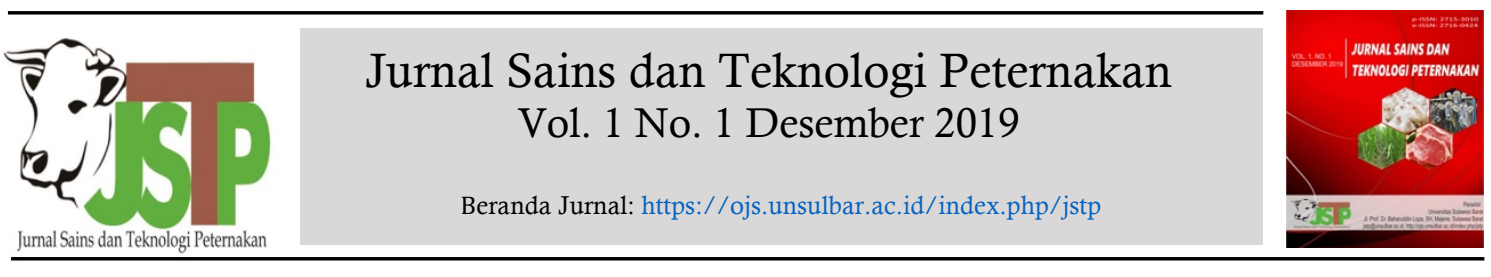

\title{
Ekstrak Etanol Daun Jati Belanda (Guazuma ulmifolia Lamk) Memperbaiki Profil Lipid Tikus (Rattus norvegicus) Wistar Jantan Dislipidemia
}

(Ethanol Extract of Jati (Guazuma ulmifolia Lamk) leaves Improve Lipid Profile of Rats (Rattus norvegicus) Wistar Male Dyslipidemia

Melita Hidajat ${ }^{1}$, I Gusti Made Aman ${ }^{2}$, Alex Pangkahila ${ }^{3}$, Hendro Sukoco ${ }^{4}$, Ferbian Milas Siswanto $5^{*}$

${ }^{1}$ Program Magister Biomedik, Fakultas Kedokteran, Universitas Udayana, Bali 80361

${ }^{2}$ Departemen Farmakologi, Fakultas Kedokteran, Universitas Udayana, Bali 80361

${ }^{3}$ Departemen Fisiologi, Fakultas Kedokteran, Universitas Udayana, Kampus Bukit, J1. Raya Kampus Unud Jimbaran, Kec. Kuta Sel., Kabupaten Badung, Bali 80361

${ }^{4}$ Prodi Peternakan, Fakultas Peternakan dan Perikanan, Universitas Sulawesi Barat, J1. Prof. Dr. Baharuddin Lopa, S.H., Baurung, Banggae Timur, Baurung, Banggae Timur, Kabupaten Majene, Sulawesi Barat 91412

${ }^{5}$ Program Studi Bioteknologi, Fakultas Ilmu Kesehatan Sains dan Teknologi, Universitas Dhyana Pura, J1. Raya Padang Luwih, Tegaljaya, Dalung, Kec. Kuta Utara, Kabupaten Badung, Bali 80361

\section{A R T I C L E I N F O}

Received: 20 November 2019 Accepted: 28 Desember 2019

*Corresponding author ferbianms@undhirabali.ac.id

Keywords:

Dyslipidemic

Jati leaves extract

Lipid profile

Rats Wistar

\section{A B S T R A C T}

The purpose of this study was to prove that the administration of Jati (Guazuma ulmifolia Lamk) leaves extract improves the lipid profile of dyslipidemic male Wistar rats. Subjects were 20 rats (Rattus norvegicus), male, Wistar strain, dyslipidemia (total cholesterol $\geq 200 \mathrm{mg} / \mathrm{dl}$ ), aged 2 months old, weighing 180-200 grams. The control group (10 rats) were given a placebo of $3 \mathrm{ml}$ aquadest (P0) and the treatment group was given extracts of the Jati (Guazuma ulmifolia Lamk) leaves extract of $25 \mathrm{mg} / \mathrm{kg} \mathrm{BW}$ (P1). Before and after treatment for 14 days, total cholesterol, triglyceride, LDL, and HDL levels were examined. The results showed that in the P0 group there were no changes in total cholesterol, triglyceride, LDL, and HDL levels ( $p>0.05$ ), whereas the P1 group experienced a decrease in total cholesterol, triglyceride and LDL levels $(p<0.05)$ and an increase in HDL levels $(p<0.05)$. The results of this study indicated that the Jati leaves extract was effective to improve the lipid profile of dyslipidemic rats. It was necessary to compare the effectiveness of Jati leaves extract with synthetic dyslipidemia drugs used in the community such as statin. 


\author{
Kata Kunci: \\ Dislipidemia \\ Ekstrak daun Jati Belanda \\ Profil lipid \\ Tikus Wistar
}

\begin{abstract}
A B S T R A K
Tujuan penelitian ini adalah untuk membuktikan bahwa pemberian ekstrak daun Jati Belanda (Guazuma ulmifolia Lamk) dapat memperbaiki profil lipid pada darah tikus Wistar jantan dislipidemia. Subjek yang digunakan adalah 20 ekor tikus putih (Rattus norvegicus), jantan, galur Wistar, dislipidemia (kolesterol total $\geq 200 \mathrm{mg} / \mathrm{dl}$ ), usia 2 bulan, berat badan 180-200 gram. Kelompok kontrol (10 ekor) diberikan plasebo berupa $3 \mathrm{ml}$ aquadest (P0) dan kelompok perlakuan diberikan ekstrak daun Jati Belanda (Guazuma ulmifolia Lamk) dosis $25 \mathrm{mg} / \mathrm{kg}$ BB tikus (P1). Sebelum dan sesudah perlakuan selama 14 hari, kadar kolesterol total, trigliserida, LDL, dan HDL diperiksa pada serum. Hasil menunjukkan pada kelompok P0 tidak terdapat perubahan kadar kolesterol total, trigliserida, LDL, dan HDL $(\mathrm{P}>0,05)$, sebaliknya kelompok P1 mengalami penurunan kadar kolesterol total, trigliserida dan LDL $(\mathrm{P}<0,05)$ serta peningkatan kadar HDL $(\mathrm{P}<0,05)$. Hasil penelitian ini mengindikasikan bahwa ekstrak daun Jati Belanda (Guazuma ulmifolia Lamk) efektif untuk memperbaiki profil lipid tikus dislipidemia. Selanjutnya perlu dilakukan komparasi efektifitas ekstrak daun Jati Belanda dengan obat dislipidemia sintetik yang digunakan di masyarakat seperti obat golongan statin.
\end{abstract}

\section{Pendahuluan}

Dipylidiasis Meningkatnya status sosioekonomi dan perubahan gaya hidup termasuk pola makan menyebabkan asupan lemak jenuh meningkat, sedangkan aktivitas fisik makin berkurang (sedentary lifestyle). Konsumsi lemak jenuh tinggi dan kurangnya aktivitas fisik akan menyebabkan penimbunan lemak di jaringan lemak (Haryanto, Pangkahila, Aman, \& Siswanto, 2019). Hal ini menginduksi sekresi sitokin seperti TNF- $\alpha$ (tumor necrosis factor-alpha), yang kemudian menyebabkan terjadinya resistensi insulin, menekan oksidasi asam lemak pada hepar, meningkatkan sintesis kolesterol oleh sel hepar (Ramírez \& Sánchez, 2012). Secara umum kondisi ini akan menimbulkan kelainan metabolisme lemak darah yang dikenal sebagai dislipidemia.

Dislipidemia adalah kelainan dari metabolisme lipoprotein, yaitu overproduksi ataupun defisiensi dari lipoprotein tertentu. Dislipidemia dapat bermanifestasi sebagai peningkatan konsentrasi kolesterol total, trigliserida, dan low-density lipoprotein (LDL) serta penurunan high-density lipoprotein (HDL) dalam darah (Widhiantara, Permatasari, Siswanto, \& Dewi, 2018). Keadaan ini sering diikuti dengan sindrom metabolik. Karena dislipidemia meningkatkan resiko penyakit metabolic dan penyakit degenerative lainnya, maka dislipidemia dianggap sebagai salah satu penyebab penuaan dini dan penyebab kematian karena itu pencegahan dan penanganan dislipidemia sangatlah penting (Kartiko \& Siswanto, 2015). Penanganan yang benar terhadap dislipidemia dapat menurunkan risiko penyakit kardiovaskular pada pasien overweight dan obesitas (Bays et al., 2013).

Terdapat dua macam terapi dislipidemia, yaitu terapi non-farmakologis (olah raga secara teratur dan mengatur gaya hidup) dan terapi farmakologis. Terapi farmakologis yang ada sekarang seperti lovastatin, klofibrat, gemfibrozil harganya relatif cukup mahal dan memiliki efek samping, seperti miositis, dapat merusak fungsi hati, dan lain-lain. Upaya pengobatan alamiah yang dapat memperbaiki profil lipid sangat penting dilakukan. Selain murah dan mudah didapat, memiliki risiko efek samping yang kecil sehingga relatif aman jika dibandingkan dengan obat-obat sintesis (Gravina, Bertolami, \& Rodrigues, 2012; Zodda, Giammona, \& Schifilliti, 2018).

Indonesia terletak di daerah tropis dan memiliki keanekaragaman hayati yang cukup tinggi bila dibandingkan dengan daerah beriklim subtropis (iklim sedang) dan iklim kutub. Salah satu dari berbagai tanaman itu adalah Jati Belanda (Guazuma ulmifolia Lamk) yang banyak tumbuh di sekitar kita. Daun Jati Belanda sendiri dipercaya dan telah dimanfaatkan oleh banyak lapisan masyarakat untuk menurunkan kadar 
kolesterol (Sari, Nurrochmad, \& Setiawan, 2013). Namun secara empiris, efek daun Jati Belanda terhadap profil lipid masih harus dibuktikan.

\section{Materi dan Metode}

Penelitian ini adalah penelitian eksperimental dengan menggunakan rancangan pretest - posttest control group design. Subjek dalam penelitian ini adalah 20 ekor tikus putih (Rattus norvegicus), jantan, galur Wistar, dislipidemia (kolesterol $\geq 200 \mathrm{mg} / \mathrm{dl}$ ), usia 2 bulan, dengan berat badan 180 - 200 gram. Dislipidemia pada tikus diinduksi secara eksperimental dengan pemberian pakan tinggi kolesterol yang terdiri dari kolesterol $1 \%$, kuning telur $5 \%$, lemak babi $10 \%$, minyak goreng $1 \%$, dan makanan standar sampai $100 \%$ selama 4 minggu. Setelah dislipidemia (kolesterol $\geq 200 \mathrm{mg} / \mathrm{dl}$ ), tikus dibagi menjadi dua kelompok masing-masing 10 ekor tikus, yaitu kelompok kontrol dengan pemberian plasebo berupa aquadest sebanyak 3 ml (P0) selama 2 minggu, dan kelompok perlakuan dengan pemberian ekstrak daun Jati Belanda (Guazuma ulmifolia Lamk) dosis 25 $\mathrm{mg} / \mathrm{kg}$ BB tikus (P1) selama 2 minggu.

Sebelum dan setelah 2 minggu perlakuan, tikus dipuasakan selama 8 jam dan dilakukan pengambilan darah pada pembuluh darah medial canthus sinus orbitalis pada semua kelompok untuk pemeriksaan profil lipid. Kadar kolesterol total, LDL, HDL dan trigliserida diukur dengan metode GOD PAP. Data dianalisis komparabilitas menggunakan $t$-independent Test, dan uji efek perlakuan dianalisis menggunakan Paired T Test.

\section{Hasil dan Pembahasan}

Pada penelitian ini, ekstrak etanol daun Jati Belanda diuji kandungan fitokimianya secara in vitro dan terbukti mengandung flavonoid $651,4100 \mathrm{mg} / 100 \mathrm{~g} \mathrm{QE}$, kadar total fenol 983,2200 mg/100g QE, kadar tanin 424,7600 mg/100g QE, kadar antosianin 487,4800 $\mathrm{mg} / 100 \mathrm{~g} \mathrm{QE}$, dan Inhibitor Concentration (IC) $50 \% 4,15670 \mathrm{mg} / \mathrm{ml}$.

Secara in vivo, hasil penelitian menunjukkan rerata kadar kolesterol total paska induksi obesitas dan sebelum perlakuan (pretest) pada

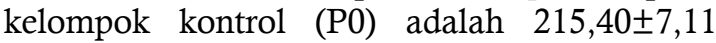
$\mathrm{mg} / \mathrm{dl}$ sedangkan pada kelompok perlakuan (P1)

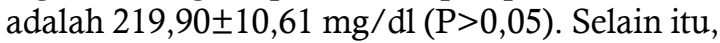
hasil analisis menunjukkan kadar trigliserida

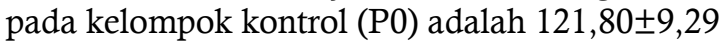
$\mathrm{mg} / \mathrm{dl}$ sedangkan pada kelompok perlakuan (P1) adalah $116,50 \pm 12,87 \mathrm{mg} / \mathrm{dl}(\mathrm{P}>0,05)$. Sebelum perlakuan, kadar HDL pada kelompok kontrol (P0) adalah 51,00 $\pm 3,37 \mathrm{mg} / \mathrm{dl}$ sedangkan pada kelompok perlakuan (P1) adalah 49,40 $\pm 3,95$ $\mathrm{mg} / \mathrm{dl}(\mathrm{P}>0,05)$. Kadar LDL pada kelompok

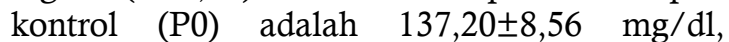
sedangkan pada kelompok perlakuan (P1) adalah

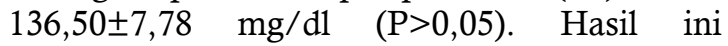
menunjukkan bahwa sebelum perlakuan, rerata kadar kolesterol total, trigliserida, HDL dan LDL pada kedua kelompok adalah tidak berbeda.

Setelah perlakuan selama 2 minggu (posttest), kadar kolesterol total pada kelompok kontrol (P0) adalah 209,20 $\pm 14,59$ mg/dl sedangkan pada kelompok perlakuan (P1) adalah $139,20 \pm 8,28 \mathrm{mg} / \mathrm{dl}(\mathrm{P}<0,05)$. Selain itu, hasil analisis menunjukkan kadar trigliserida pada

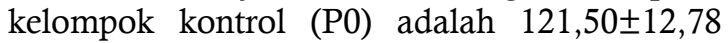
$\mathrm{mg} / \mathrm{dl}$ sedangkan pada kelompok perlakuan (P1)

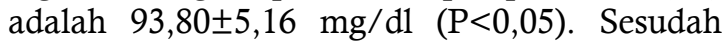
perlakuan, kadar HDL pada kelompok kontrol

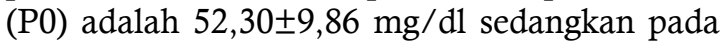

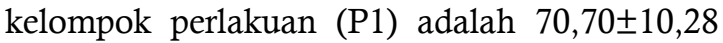
$\mathrm{mg} / \mathrm{dl}(\mathrm{P}<0,05)$. Kadar LDL pada kelompok kontrol (P0) adalah 130,60 $\pm 11,54 \mathrm{mg} / \mathrm{dl}$ sedangkan pada kelompok perlakuan (P1) adalah

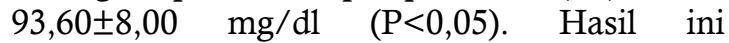
menunjukkan bahwa sesudah perlakuan, rerata kadar kolesterol total, trigliserida, HDL dan LDL pada kedua kelompok adalah berbeda $(\mathrm{P}<0,05)$. Analisis efek perlakuan menunjukkan bahwa pada kelompok kontrol (P0) tidak terjadi perubahan kadar kolesterol total, trigliserida, HDL dan LDL $(\mathrm{P}>0,05)$, namun sebaliknya pada kelompok perlakuan (P1) dapat diamati terjadinya penurunan kadar kolesterol total, trigliserida dan LDL $(\mathrm{P}<0,05)$ disertai dengan peningkatan HDL yang $(\mathrm{P}<0,05)(\mathrm{Gambar} 1)$.

Pada penelitian ini ekstrak daun Jati Belanda (Guazuma ulmifolia Lamk) dosis 25 $\mathrm{mg} / \mathrm{kg}$ BB tikus terbukti dapat menurunkan kadar kolesterol total, trigliserida, LDL dalam darah serta meningkatkan HDL dalam darah. Hal ini disebabkan karena ekstrak daun Jati Belanda (Guazuma ulmifolia Lamk) dosis 25 $\mathrm{mg} / \mathrm{kg}$ BB tikus terbukti mengandung flavonoid, tannin, antosianin dan kapasitas antioksidan berdasarkan hasil analisis fitokimia.

Ekstrak daun Jati Belanda (Guazuma ulmifolia Lamk) mengandung flavonoid sebesar 651,41 mg/100g QE. Flavonoid telah terbukti dapat memperbaiki profil lipid darah dan mencegah kerusakan testis pada tikus yang dislipidemia (Amani, Moazen, Shahbazian, Ahmadi, \& Jalali, 2014; Widhiantara, Permatasari, et al., 2018). Flavonoid merupakan kelompok senyawa fenol yang terbesar ditemukan di alam yang berpotensi sebagai 
antioksidan dan mempunyai bioaktivitas sebagai obat (Widhiantara, Arunngam, \& Siswanto, 2018). Flavonoid dapat menangkap radikal bebas dan mencegah proses peroksidasi lipid di mikrosom dan liposom (Mandić et al., 2019). Flavonoid memiliki kemampuan untuk menginhibisi CETP (Cholesteryl ester transfer protein). Dengan menekan aktivitas CETP, maka dapat meningkatkan kadar kolesterol HDL dan menurunkan kadar kolesterol LDL. CETP adalah protein plasma yang memediasi pertukaran cholesteryl ester dari HDL ditukar dengan molekul trigliserida dari LDL, VLDL maupun kilomikron, sehingga yang terjadi VLDL kaya akan kolesterol, sedangkan HDL menjadi kaya akan trigliserida atau dikenal sebagai lipoprotein kaya trigliserida (TGrL). Apo A-1 dapat memisahkan diri dari HDL kaya trigliserida. ApoA-1 bebas ini segera dibersihkan dari plasma, melalui ginjal, sehingga mengurangi kemampuan HDL untuk reverse cholesterol transport. Akibatnya kadar HDL dalam darah menurun. LDL kaya trigliserida dapat mengalami lipolisis menjadi small dense LDL. Dalam hal ini flavonoid bekerja menghambat CETP sehingga terjadi peningkatan kadar HDL kolesterol dan penurunan kadar LDL. Flavonoid juga memiliki efek anti inflamasi dengan menghambat sitokin seperti tumor necrosis factor $\alpha \quad(\mathrm{TNF}-\alpha)$. Penurunan TNF- $\alpha$ akan meningkatkan sensitivitas insulin, meningkatkan oksidasi asam lemak pada hepar, menghambat sintesis kolesterol oleh sel hepar (Haryanto et al., 2019).
Selain flavonoid, ekstrak ekstrak daun Jati Belanda (Guazuma ulmifolia Lamk) juga mengandung tanin sebanyak $424,76 \mathrm{mg} / 100 \mathrm{~g}$ QE. Tanin yang tergolong sebagai polifenol telah terbukti mampu meningkatkan penyerapan glukosa pada jaringan adiposit tikus GLUT4. Tanin menunjukkan potensi dalam menginduksi penyerapan glukosa yang setara dengan $100 \mathrm{~nm}$ insulin dan tanin mencapai penyerapan glukosa maksimal di kisaran $24-49 \%$ pada konsentrasi di bawah $1 \mathrm{mg} / \mathrm{ml}$ (Widhiantara, Arunngam, et al., 2018).

Total polifenol pada ekstrak daun Jati Belanda (Guazuma ulmifolia Lamk) adalah 983,22 $\mathrm{mg} / 100 \mathrm{~g}$ QE. Polifenol sebagai antioksidan mempunyai efek yang menguntungkan pada fungsi endotel yaitu menurunkan oksidasi LDL dan meningkatkan produksi nitrit oxide (NO). Polifenol mempunyai aktivitas antioksidan yang berfungsi menangkal radikal bebas serta mencegah proses oksidasi LDL. Polifenol juga dapat menurunkan sekresi lipoprotein yang terdapat di hepar dan usus. Polifenol ini mengurangi proses eterifikasi kolesterol sehingga terjadi penurunan kadar ester kolesterol (komponen pembentuk utama kilomikron dan VLDL; serta menghambat sintesis Apo B-48 dan Apo B-100 yang disintesis di dalam enterosit dan hepar. Kadar Apo B-48 dan Apo B-100 yang menurun menyebabkan pembentukan kilomikron, VLDL, IDL, dan LDL terganggu sehingga kadar trigliserida darah juga menurun (Ehrman, Gordon, Visich, \& Keteyian, 2009).

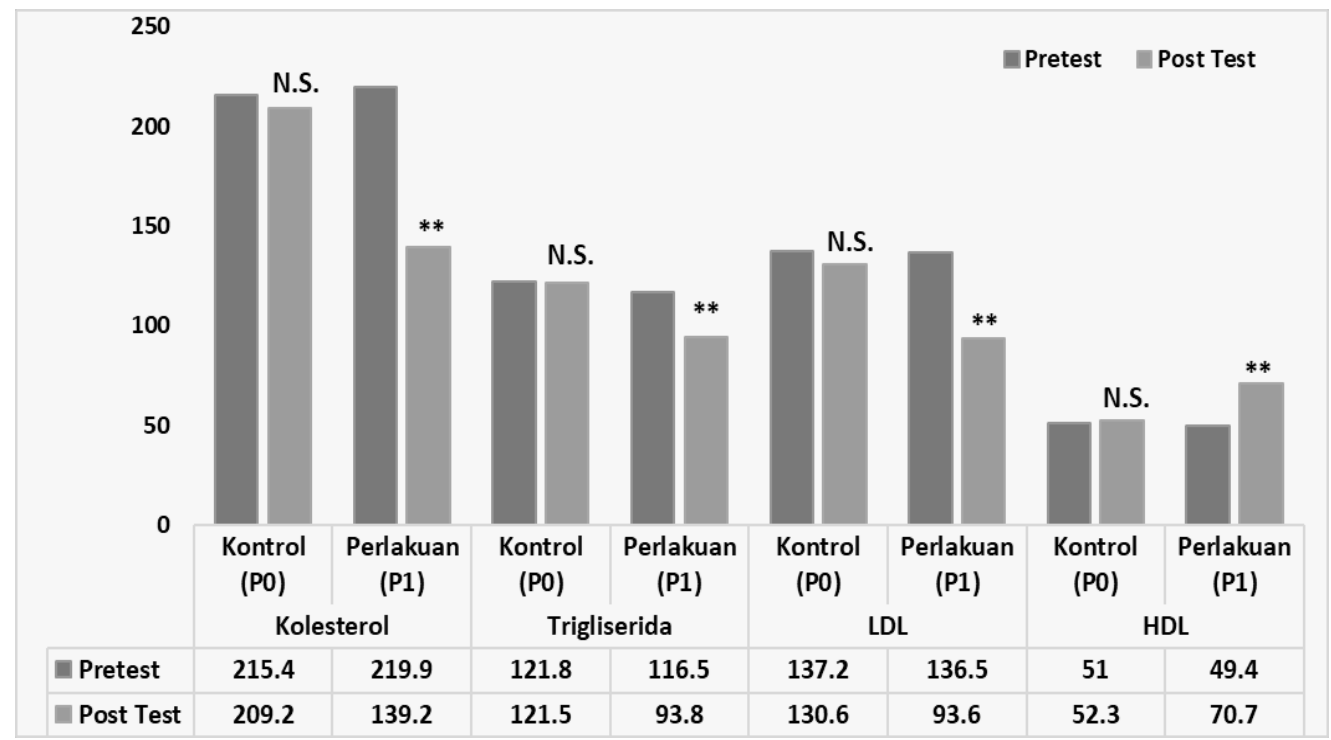

Gambar 1. Grafik perubahan profil lipid sebelum dan sesudah perlakuan antar kelompok. N.S.: Tidak signifikan $(\mathrm{P}>0,05), * *$ : Signifikan $(\mathrm{P}<0,05)$ dianalisis dengan menggunakan paired T test.

Antosianin pada ekstrak daun Jati Belanda (Guazuma ulmifolia Lamk) adalah sebanyak
$487,98 \mathrm{mg} / 100 \mathrm{~g}$ QE juga memiliki kemampuan untuk menginhibisi CETP (Cholesteryl ester 
transfer protein). Dengan menekan aktifitas CETP, maka dapat meningkatkan kadar kolesterol HDL dan menurunkan kadar kolesterol LDL. Antosianin juga memiliki efek anti inflamasi dengan menghambat sitokin seperti tumor nekrosis $\alpha(\mathrm{TNF}-\alpha)$. Penurunan TNF- $\alpha$ akan meningkatkan sensitivitas insulin, meningkatkan oksidasi asam lemak pada hepar, menghambat sintesis kolesterol oleh sel hepar (Ehrman et al., 2009).

Bila dibandingkan, ekstrak daun Jati Belanda memiliki kandungan flavonoid, tanin, dan senyawa antioksidan yang lebih tinggi dibanding tanaman lain, sehingga lebih efektif dalam menurunkan kadar kolesterol seseorang. Daun Jati Belanda selain menurunkan kadar kolesterol, trigliserida, LDL juga meningkatkan HDL, dengan cara meningkatkan kerja enzim lipoprotein lipase (Sari et al., 2013).

Pada penelitian ini dengan adanya perbaikan kadar profil lipid dalam keadaan dislipidemia maka dapat disimpulkan bahwa ekstrak daun Jati Belanda (Guazuma ulmifolia Lamk) dapat digunakan dalam upaya mencegah, menghambat bahkan menghambat terjadinya dislipidemia. Penelitian lebih lanjut tetap harus dilakukan dengan variasi dosis dan lama pemberian ekstrak daun Jati Belanda (Guazuma ulmifolia Lamk) ini untuk mengetahui efek dalam memperbaiki profil lipid darah.

\section{Kesimpulan}

Berdasarkan hasil penelitian ini, dapat disimpulkan bahwa ekstrak daun Jati Belanda (Guazuma ulmifolia Lamk) efektif untuk memperbaiki profil lipid tikus dislipidemia. Selanjutnya perlu dilakukan komparasi efektifitas ekstrak daun Jati Belanda dengan obat dislipidemia sintetik yang digunakan di masyarakat seperti obat golongan statin. Pemberian ekstrak daun Jati Belanda sebagai terapi alamiah dalam memperbaiki profil lipid pada penderita dislipidemia dapat memperbaiki kualitas hidup penderita secara signifikan, namun hal ini dapat diimplementasikan setelah melalui clinical trial.

\section{Daftar Pustaka}

Amani, R., Moazen, S., Shahbazian, H., Ahmadi, K., \& Jalali, M. T. (2014). Flavonoid-rich beverage effects on lipid profile and blood pressure in diabetic patients. World Journal of Diabetes, 5(6), 962-968. https://doi.org/10.4239/wjd.v5. i6.962
Bays, H. E., Toth, P. P., Kris-Etherton, P. M., Abate, N., Aronne, L. J., Brown, W. V., ... La Forge, R. (2013). Obesity, adiposity, and dyslipidemia: a consensus statement from the National Lipid Association. Journal of Clinical Lipidology, 7(4), 304-383. https://doi.org/10.1016/j.jacl.2013.04.00 1

Ehrman, J. K., Gordon, P. M., Visich, P. S., \& Keteyian, S. J. (2009). Clinical Exercise Physiology (2nd ed.). Champaign: Human Kinetics.

Gravina, C. F., Bertolami, M., \& Rodrigues, G. H. P. (2012). Dyslipidemia: evidence of efficacy of the pharmacological and nonpharmacological treatment in the elderly. Journal of Geriatric Cardiology, 9(2), 83-90. https://doi.org/10.3724/SP.J.1263.2011. 12292

Haryanto, P., Pangkahila, A., Aman, I. G. M., \& Siswanto, F. M. (2019). Pengaruh latihan fisik intensitas sedang terhadap jumlah reseptor insulin di jaringan lemak tikus jantan obesitas. eJournal Kedokteran Indonesia, 7(1), 23-27. https://doi.org/10. 23886/ejki.7.9587

Kartiko, B. H., \& Siswanto, F. M. (2015). Hormon dalam konsep anti aging medicine. VIRGIN: Jurnal Ilmiah Kesehatan dan Sains, 1(2), 108-122.

Mandić, L., Sad ak, A., Strasser, V., Baranović, G., Domazet Jurašin, D., Dutour Sikirić, M., \& Šegota, S. (2019). Enhanced protection of biological membranes during lipid peroxidation: study of the interactions between flavonoid loaded mesoporous silica nanoparticles and model cell membranes. International Journal of Molecular Sciences, 20(11), 1-22. https:// doi.org/10.3390/ijms20112709

Ramírez, A. M. M., \& Sánchez, R. C. (2012). Tumor necrosis factor- $\alpha$, insulin resistance, the lipoprotein metabolism and obesity in humans. Nutricion Hospitalaria, 27(6), 17511757. https://doi.org/10.3305/nh.2012.27 .6 .6004

Sari, I. P., Nurrochmad, A., \& Setiawan, I. M. (2013). Indonesian herbals reduce cholesterol levels in diet-induced hypercholesterolemia through lipase inhibition. Malaysian Journal of Pharmaceutical Sciences, 11(1), 13-20.

Widhiantara, I. G., Arunngam, P., \& Siswanto, 
F. M. (2018). Ethanolic extract of Caesalpinia bonducella f. seed Ameliorates diabetes phenotype of StreptozotocinNicotinamide-Induced type 2 diabetes rat. Biomedical and Pharmacology Journal, 11(2), 1127-1133. https://doi.org/10.13005/bpj $/ 1473$

Widhiantara, I. G., Permatasari, A., Siswanto, F. M., \& Dewi, N. P. E. S. (2018). Ekstrak daun Sembung (Blumea balsamifera) memperbaiki histologi testis tikus Wistar yang diinduksi pakan tinggi lemak. Jurnal Bioteknologi \& Biosains Indonesia, 5(2), 111118.

Zodda, D., Giammona, R., \& Schifilliti, S. (2018). Treatment strategy for dyslipidemia in cardiovascular disease prevention: Focus on old and new drugs. Pharmacy, 6(1), $1-$ 16. https://doi.org/10.3390/pharmacy601 0010 